\title{
Why are dermatologists happy?
}

\author{
José Luis Sandoval-Gutiérrez
}

Secretaría de Salud, Instituto Nacional de Enfermedades Respiratorias "Ismael Cosío Villegas", Department of Pulmonology, Ciudad de México, Mexico

Fierro-Arias et al. ${ }^{1}$ report an interesting work about job satisfaction and happiness in professionals of their specialty.

The definition of happiness, according to the dictionary of The Royal Spanish Academy, states: ${ }^{2}$

From Lat. felicitas, -ātis.

1. f. State of pleasant spiritual and physical satisfaction.

2. f. Person, situation, object or group thereof that contribute to making someone happy.

3. f. Absence of inconveniences or stumbles.

In any professional activity, the degree of satisfaction it can produce in the subject is important, as a condition for achieving a professional-personal balance.

The setting where a vocation develops can cause for the initial pleasure whereby taking this path was decided to turn hostile, with doubts likely arising about the attitudes of dedication, love and identification that were present initially.

Recent events in the Mexican medical community of professionals emphasize the need for improvement in the administrative, structural, wage and procedural situation for a full medical performance in a professional and pleasant environment. ${ }^{3,4}$

If a foreigner reads the manuscript of the aforementioned authors, he or she will find that Mexico apparently offers superb field for the development of dermatology, since $93 \%$ of surveyed subjects expressed being highly satisfied with their specialty and $98.6 \%$ would choose it again, with an average of 16 years of practice.

Other fields of medicine (such as oncology, intensive therapy, general surgery or emergency medicine, among others) have shown characteristics that define them, but generally there is not a high degree of satisfaction and happiness, especially during the first years of training.

Someone might ask, why does a doctor choose those specialties? Someone else might answer that "by vocation", which in the dictionary is defined as follows: 5

From Lat. vocatio, -ōnis 'act of calling'.

1. f. Inspiration whereby God calls to some state, especially to religion.

\section{2. f. dedication.}

3. f. Inclination to a state, a profession or a career.

4. f. archaic. Convocation, appeal.

Therefore, someone can be performing an activity because of the enormous need to satisfy a vocation, without necessarily reaching a state of complete satisfaction or happiness, although it is desirable for vocation-satisfaction-happiness to be aligned and to be close to $100 \%$.

The new generations of learners, the so-called millennials, ${ }^{6}$ appear more interested on things that produce immediate satisfaction, which sometimes they consider wrong referring to as "happiness", leaving real vocation in the background, with, the latter being a necessary condition for medicine optimal performance.

The study in question refers $72.6 \%$ of females. Is it that females are more optimistic? ${ }^{7}$ It describes the national education centers the specialists graduated from, but it does not indicate if they are working in public or private institutions or in both.

In Mexico, it is necessary for studies to be carried out evaluating different specialties, since each one has special conditions and needs.

The medical community needs to be taken care of in this psychological need, since as one journalist once said:
Gac Med Mex. 2018;154:421-422

Contents available at PubMed www.gacetamedicademexico.com 
We all will need a doctor sometime in life, so, the better we treat them, the better will they look after us.

\section{References}

1. Fierro-Arias L, Simón-Díaz $P$, Ponce-Olivera RM, Arenas-Guzmán $R$. Estudio sobre la satisfacción laboral y la felicidad en médicos dermatólogos. Gac Med Mex. 2018;154:26-35.

2. Real Academia Española. [Sitio web]. Felicidad. Disponible en: http://dle. rae.es/?id=Hj4JtKkmn.

3. Pérez-Méndez LA. Liberan a médico acusado de muerte del niño Edward en Oaxaca. Excélsior. 2018 Abr 13. Disponible en: https://www.excelsior. com.mx/nacional/liberan-a-medico-acusado-de-muerte-del-nino-edward-en-oaxaca/1232189.

4. Noticias, voz e imagen de Oaxaca. [En línea]. Ceden jueces y magistrados ante marcha de médicos en Oaxaca: familiares de Edward. [Consultado $2018 \mathrm{Abr}$ 14]. Disponible en http://www.nvinoticias.com/ nota/89545/ceden-jueces-y-magistrados-ante-marcha-de-medicos-en-oaxaca.

5. Real Academia Española. [En línea]. Vocación. [Consultado 2018 Abr 16]. Disponible en: http://dle.rae.es/?id=bzINevX

6. Waljee JF, Chopra V, Saint S. Mentoring Millennials. JAMA 2018;319:1547-1548.

7. Mariano Osorio. [Sitio web]. Las mujeres optimistas viven más. [Consultado 2018 Abr 17]. Disponible en: https://marianoosorio.com/blogs/noticias-que-te-hacen-bien/las-mujeres-optimistas-viven-mas. 